\title{
Sustainable Energy Management in Historical Environment; Example of Sivrihisar Solar Water Heating Systems
}

\author{
Hicran Hanım Halaç ${ }^{1}$, Veli Öğülmüş ${ }^{2 *}$ \\ 1 Eskişehir Technical University, Faculty of Architecture and Design, Departmant of Architecture, Eskişehir, Turkey, (ORCID: 0000-0001-8046-9914), hhhalac@eskisehir.edu.tr \\ 2* Eskişehir Technical University, Faculty of Architecture and Design, Departmant of Architecture, Eskişehir, Turkey, (ORCID: 0000-0001-8156-3582), veliogulmus@eskisehir.edıu.tr
}

(First received 31 May 2021 and in final form 13 November 2021)

(DOI: 10.31590 /ejosat.945304)

ATIF/REFERENCE: Hanım Halaç, H. \& Öğülmüş, V. (2021). Sustainable Energy Management in Historical Environment; Example of Sivrihisar Solar Water Heating Systems. European Journal of Science and Technology, (27), 911-920.

\begin{abstract}
As the sustainability principle began to manifest itself more in 21 st-century buildings, renewable energy-based systems used as a requirement of this principle are frequently seen in architecture. The most prominent of these are Solar Energy Systems. In this respect, as a result of the buildings' efforts to coexist with this technology, components of Solar Water Heating Systems (SWHS), a new architectural element, started to be included in the buildings. Even though these mechanisms have advantages make our lives easier and serve the sustainability principles, the increasing use of them rapidly in the buildings brings about some problems such as aesthetical, and structural. As a consequence of such problems arising with these systems' widespread use in residential areas, it is essential to examine these additions' relations with buildings and the urban environment. If the buildings that are part of the cultural heritage has these systems require conservation and are located in the historical texture, it is even more essential to emphasize. To manage the sustainability of historical environments, these systems' existence should be determined in either building at historical settlements or registered buildings, and some arrangements should be made by examining their relations with buildings. Considering all, it is aimed to analyze and evaluate the relations of these systems and buildings within the Sivrihisar Urban Protected Area, which has historical and cultural importance in Eskişehir. The study of the data obtained from the buildings in these regions through fieldwork was handled with comparative graphical, mapping methods, and supported with visual representation ways.
\end{abstract}

Keywords: Solar Water Heating Systems, Renewable Energy, Historical Texture, Cultural Heritage, Sivrihisar.

\section{Tarihi Çevrede Sürdürülebilir Enerji Yönetimi: Sivrihisar Güneş Enerjili Su Isitma Sistemleri Örneği}

$\ddot{O} \mathbf{z}$

Sürdürülebilirlik ilkesinin 21. yüzyıl yapılarında kendini daha çok göstermeye başlamasıyla birlikte, bu ilkenin gereği olarak yararlanılan yenilenebilir enerjiye dayalı sistemler mimaride sıklıkla kullanılmaya başlanmıştur. Bunların içinde en fazla öne çıkanları Güneş Enerjisi Sistemleridir. Bu doğrultuda binaların bu teknoloji ile bir arada var olma çabaları sonucunda yeni bir mimari eleman olan Güneş Enerjili Su Isıtma Sistemleri (GESIS) bileşenleri binalarda yer almaya başlamıştır. Bu mekanizmaların hayatımızı kolaylaştıran ve sürdürülebilirlik ilkelerine hizmet eden avantajları olmasına rağmen, binalarda hızla artan kullanımı estetik ve yapısal bazı sorunları da beraberinde getirmektedir. Bu sistemlerin yerleşim alanlarında yaygın olarak kullanılmasıyla ortaya çıkan sorunsalların bir sonucu olarak, bu eklentilerin binalar ve kentsel çevre ile olan ilişkilerinin incelenmesi elzemdir. Eğer ki tarihi doku içerisinde bulunan ve kültürel mirası yansıtan binalarda bu tip eklentiler var ise konu daha da önemli hale gelmektedir. Tarihi çevrelerin sürdürülebilirliğini yönetmek için bu sistemlerin gerek tarihi yerleşim yerlerinde yapılan binalarda gerekse tescilli binalarda varlıkları tespit edilmeli ve yapılarla olan ilişkileri analiz edilerek bazı düzenlemeler getirilmelidir. Bu çalışmada, Eskişehir'de tarihi ve kültürel öneme sahip olan Sivrihisar Kentsel Sit Alanı içerisindeki Güneş Enerjili Su Isıtma Sistemlerinin tarihi yapılarla ilişkilerinin analizinin yapılması amaçlanmıştır. Bu bölgedeki yapılardan edinilen analiz verileri saha çalışmaları sonucu elde edilmiş, karşılaştırmalı grafikler, haritalama yöntemleri ve görsel anlatım yolları ile desteklenmiştir.

Anahtar Kelimeler: Güneş Enerjili Su Isıtma Sistemleri, Yenilenebilir Enerji, Tarihi Doku, Kültürel Miras, Sivrihisar

*Corresponding Author: veliogulmus@eskisehir.edu.tr 


\section{Introduction}

The conservation and efficient use of existing resources is of great importance for the survival of human life and nature. The theme of sustainability, which is basically based on these principles, is rapidly starting to take on a more vital role for the building sector. Solar Energy Systems, which seem more effective in terms of their potential, are more common in sustainable structures that use renewable energy as a basis. Solar Heating Systems, which are used to supply the buildings' own hot water, have become extremely common. Solar Water Heating technologies are simple, reliable, and cost-effective methods of utilizing solar energy to meet the energy needs of homes and businesses (Al-badi and Al-badi, 2012). In these systems using solar energy, the energy source used to heat water is no longer electricity and fossil fuels, and it has a renewable identity. Apart from the sustainable functions that these systems bring to the structure, there are some problems that their components arise while being included in the structure. These systems, which incorporate the advantages of using solar energy effectively into the structure, can cause visual pollution in terms of aesthetics in cases of improper positioning, careless assembly, unconscious reproduction, damage to buildings and the natural environment in terms of structure.

Especially for buildings in the historical environment and in need of protection, such problems can cause much bigger ones. While interventing in buildings that can be defined as architectural and cultural heritage, damage to the building should be avoided, attention should be paid not to lose or change the building's traces, which serves as a historical document, and the integrity of the building should be preserved. Simultaneously, interventions should not be misleading for research and studies to be conducted, as they can be removed without damaging the original structure, and/or renewable methods must be used (ICOMOS Turkey, 2013). In this point of view, the additions created by these systems have become an architectural design element that concerns the building with cultural heritage value and its environment, and it is essential to examine and evaluate their presence in historical regions and their relations with the buildings. However, even if there are academic studies in which these problematic issues are analyzed, evaluated, and solutions are tried to be offered within the design problems, no study is conducted on the historical environment and registered buildings. Especially in the works that Müjgan Şerefhanoğlu Sözen and Esra Sakınç dealt with in terms of architectural unity with SWHS, they talked about the problems in the context of the city and on the basis of the building. Still, this work has not included the historical context. This study aims to recognize the existence of these systems, analyze them, determine their relations with the buildings and their surroundings, and evaluate their situation to ensure the sustainability of historical environments and cultural heritage based on the studies in the literature.

As the scope of the study, the buildings within the urban site area of Sivrihisar district in the borders of Eskişehir were selected, and the relations of this region with historical and cultural value with Solar Heating Systems was examined. While presenting the analyzes, it was determined that Gedik and Kılıç Neighborhoods dominate the historical urban tissue compared to other neighborhoods. While making this determination, it was taken into account that the landmarks (Sivrihisar Great Mosque,
Watch Tower, Surp Yerotutyun Armenian Church) that are considered to be the most qualified buildings in the region and can represent Sivrihisar's cultural heritage are concentrated here. Field studies on the scale of Gedik and Kılıç neighborhoods have progressed more specifically and building-oriented. The statistical data obtained from the investigations were narrated with the help of graphics and tables. It aimed to increase the opacity of the system elements entering the viewpoint to better understand the existence of these systems in the historical texture thanks to visual representations. In this study, preliminary information about SWHS will be given first, the areas of use, types, and advantages are going to be mentioned. The relations of these components with the buildings are going to be conveyed. Their presence in Sivrihisar Urban Site will be understood, some results and suggestions will be expressed by analyzing the neighborhoods of Kilıç and Gedik.

\subsection{Solar Water Heating Systems}

Solar energy, among renewable energy sources; the potential it carries is more useful in terms of the access's width, and it responds to many requirements in buildings through heat and light energy. Active exploitation systems developed to benefit from solar radiation more effectively; Especially in recent years, with technological developments, it has become possible to produce heat and electrical energy, use them where necessary, and easily apply them in buildings. Chiefly among these systems, Solar Heating Systems are the ones that have gained the most usage in cities in the 21st century. Solar Heating Systems are all electronic or mechanical systems that transform these radiations into heat energy with collectors' help and use this energy directly or in a storage unit through a fluid such as air or water (Energy Efficiency Best Practice Programme, 2001). Although Solar Heating Systems differ in systems depending on the complexity and size of the requirement, the working principle of all of them is based on the heating, storage, and distribution of water. In these systems, when the primary purpose is to heat and use water, they are called Solar Water Heating Systems (SWHS). Looking at the historical process; In 1958, the solar water heater was first used in China. The thermosiphon circulation solar water heater developed by Tianjin University was used in a $12.6 \mathrm{~m} 2$ bathroom. Since the energy crisis of the 1970s, the use of renewable energy has become a worldwide attraction (Shi et al., 2013). Interest and interest in these systems have also started to increase since then. Also, a solar water heating system for the first time in 1975 in Izmir has used in Turkey. The Turkish community adopted it quickly, and mass production started (Arslan, 2018). The mechanisms of these systems, which have been used densely since then, are composed of four subsystems. These are the collector subsystem, storage subsystem, circuit subsystem, and control subsystem (Unified Facilities Criteria, 2002).

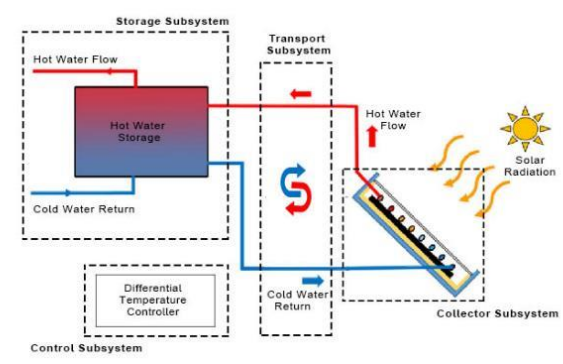

Figure 1. Solar Water Heating System Scheme (Unified Facilities Criteria, 2002). 
The mechanism of solar water heating systems has a simple systematic. The hot water is produced in the collector subsystem, which heats the cold water utilizing the sun's radiation, is carried to the tank through the transport subsystem. Hot water collected in the storage subsystem supplies water as much as the building needs. During these operations, the control subsystem also manages the cycle in an active role (Figure 1)

Self circulating systems are mostly used for small amounts of water needs. They cannot be applied in large systems due to the fact that the storage is located above. Since it does not require a pump and automatic control circuit, it is slightly cheaper than pump systems. Forced circulation systems are based on the circulation of the heat transfer fluid in the system with a pump. In these systems, the storage is not required to be above the level of the collectors. Open systems are systems in which the domestic water and the water circulating in the collectors are the same. Compared to closed systems, their efficiency is higher, and their cost is cheap (Table 1). They are used in areas with no lime in water and freezing problems. Closed systems are systems in which domestic water and heating water are different. If we look at these systems comparatively, we can see that all systems have certain advantages and disadvantages. When making a choice, it is aimed that the system is suitable for climatic conditions, environmental factors, and architectural features. Self circulating / open circuit systems, also known as thermosiphon type water heater, is the most widely used water heating systems because they are economical and easy to apply (Energy Efficiency Best Practice Programme, 2001).

Table 1. Solar Water Heating System Types and Features (Sakınç and Sözen, 2010)

\begin{tabular}{|c|c|c|c|c|}
\hline & $\begin{array}{l}\text { Self Circulating } \\
\text { Open Circuit }\end{array}$ & $\begin{array}{l}\text { Self Circulating } \\
\text { Closed Circuit }\end{array}$ & $\begin{array}{l}\text { Forced Circulating } \\
\text { Open Circuit }\end{array}$ & $\begin{array}{l}\text { Forced Circulating } \\
\text { Closed Circuit }\end{array}$ \\
\hline & STORAGE & STORAGE & PUMP & Cold water \\
\hline $\begin{array}{l}\text { System } \\
\text { Properties }\end{array}$ & $\begin{array}{l}\text {-No pump needed } \\
\text {-Fluid is domestic water } \\
\text {-Storage located above } \\
\text { collectors }\end{array}$ & $\begin{array}{l}\text {-Economical } \\
\text {-High efficiency } \\
\text {-Easy operation and } \\
\text { maintenance } \\
\text {-Simple } \\
\text {-No operating costs }\end{array}$ & $\begin{array}{l}\text {-Requires a pump } \\
\text {-Fluid is domestic water } \\
\text {-Storage can be separated } \\
\text { from collectors }\end{array}$ & $\begin{array}{l}\text {-Requires a pump } \\
\text {-Fluid has antifreeze } \\
\text { feature } \\
\text {-Storage can be separated } \\
\text { from collectors }\end{array}$ \\
\hline $\begin{array}{l}\text { Positive } \\
\text { Properties }\end{array}$ & $\begin{array}{l}\text {-Economical } \\
\text {-High efficiency } \\
\text {-Easy operation and } \\
\text { maintenance } \\
\text {-Simple } \\
\text {-No operating costs }\end{array}$ & $\begin{array}{l}\text {-Economical } \\
\text {-Suitable for cold climate } \\
\text {-Low probability of } \\
\text { freezing } \\
\text {-No operating costs } \\
\text {-No possibility of } \\
\text { corrosion }\end{array}$ & $\begin{array}{l}\text {-Flexible storage layout } \\
\text {-Does not strain } \\
\text { architecture } \\
\text {-High efficiency }\end{array}$ & $\begin{array}{l}\text {-Reliable in all conditions } \\
\text {-Suitable for cold climate } \\
\text {-Flexible storage layout } \\
\text {-Does not strain } \\
\text { architecture } \\
\text {-No freezing problem } \\
\text {-No corrosion }\end{array}$ \\
\hline $\begin{array}{l}\text { Negative } \\
\text { Properties }\end{array}$ & $\begin{array}{l}\text {-Corrosion problem } \\
\text {-Possiblity of freezing } \\
\text {-Not suitable for cold } \\
\text { climates } \\
\text {-Difficult to adapt with } \\
\text { architecture }\end{array}$ & $\begin{array}{l}\text {-Low efficiency } \\
\text {-Not flexible storage } \\
\text { layout } \\
\text {-Difficult to adapt with } \\
\text { architecture }\end{array}$ & $\begin{array}{l}\text {-Freezing problem } \\
\text {-Corrosion problem } \\
\text {-Multi component and } \\
\text { complex } \\
\text {-Operating expenses } \\
\text {-Expensive }\end{array}$ & $\begin{array}{l}\text {-Low efficiency } \\
\text {-Consumes electricity } \\
\text {-Multi component and } \\
\text { complex } \\
\text {-Operating expenses } \\
\text {-Expensive }\end{array}$ \\
\hline
\end{tabular}

\subsection{Relation of Solar Water Heating Systems with Historical Buildings}

When it is claimed to develop an architectural perspective in the relations of solar water heating systems with buildings, it is wanted to achieve a correct union with aesthetic concern. In the early days of the trend towards combining these systems with buildings, the ultimate goal seemed to maximize the degree of integration of solar elements. It was desired to take the word "integration" as a synonym for "invisibility" and conceal the fact that the solar elements are different from other building elements (Hestnes, 1999). However, the necessary attitude to ensure this e-ISSN: 2148-2683 unity was not to ignore these elements but to accept them as architectural elements and turn them into an input of the design. The key to the success of quality solar building projects is that, in most cases, architects use an aesthetic compatibility approach rather than ignore these add-ons. In this approach, solar energy elements are used as architectural elements in attractive and visible ways. This is only possible when the solar energy system's design is included in the building's design process (Hestnes, 1999). If the system elements are seen just as additions to the structure, it can be mentioned that there is a complex design process, later on. 
It is possible to encounter the existence of both Solar Heating Systems components in rural areas and urban areas. In this period, when almost everyone is aware of such add-ons, it is necessary to evaluate system components as an architectural element. Failed examples emerge when they are not considered as architectural elements and remain only as additions.

It is also possible to come across examples of unsuccessful practices in Turkey. Solar Water Heating Systems are usually added later to Turkey's buildings, applied devoid of a certain standard, and some studies cost as inexpensive systems preferred. This results in low efficiency and unsuccessful examples in terms of architecture. There are unconscious practices like this in many regions around the world. The increase of such examples in settlements jeopardizes the region's authentic existence created by the cultural and aesthetic features.

Especially in historical settlements, such practices affect not only the buildings themselves but also the cultural heritage, historical texture, and cultural values. This reveals several problems arising from the components of Solar Water Heating Systems in historical environments.

\subsection{The Problem of Solar Water Heating Systems}

Apart from the sustainable value-added by Solar Water Heating Systems to the building, some problems are caused by it. When these problems are examined in detail, the problems caused by these systems, which are found in almost every building in many cities; aesthetic problems, construction problems, health problems, and productivity-economic problems.

We can define health problems as legionary disease problems that arise in systems applied with the wrong material selection that is not cleaned regularly. In terms of efficiency and economy, we can also talk about economic losses caused by improperly designed systems. Yield losses can occur due to lack of attention to collector maintenance, inadequate material use, and improper collector orientation (Sakınç and Sözen, 2010). The lack of regulation and supervision of these systems, which almost every household implements without considering the compliance for their own needs, and the fact that this issue continues to be ignored in building designs while the new residential areas are rapidly increasing make the problem get chronic. In this context, those that form the basis of the problems we deal with and need to be examined in more detail can be expressed as the Aesthetics and Construction Problems.

For aesthetic problems, it can be classified as a group that includes the most significant problems caused by the system elements examined. When designing physical environments, it is desired to be beautified as possible. This desire for beautification is defined as aesthetics, and this concept has a significant effect on shaping and evaluating architectural products (Kuban, 1973). Aesthetics is one of the most critical factors that instill its identity and artistic value to a building. Damage to this feature in buildings for various reasons also causes a critical problem. When the negative reflections of Solar Energy Systems attached to buildings are examined in terms of aesthetic features, we can talk about the ugly results on the roofs and facades of the buildings and the visual pollution in the cities that occur for this reason (Sakınç and Sözen, 2010). In Figure 2, the dominance of the system additions in the city of Mersin in general, and the problems posed aesthetically are seen The system additions, seen at the scale of a single building reduce the building's aesthetic quality, but when it is spread throughout the city, it begins to be the problem of the whole city. These elements, which turn into aesthetic pollution in the city, threaten the cities' architectural identities and aesthetic integrity. The consequences of these additions' proliferation are seen much more critical, especially in regions with historical value and in protected areas designated as urban protected areas. In this respect, additions of solar water heating systems have become a problem for cities to deal with.

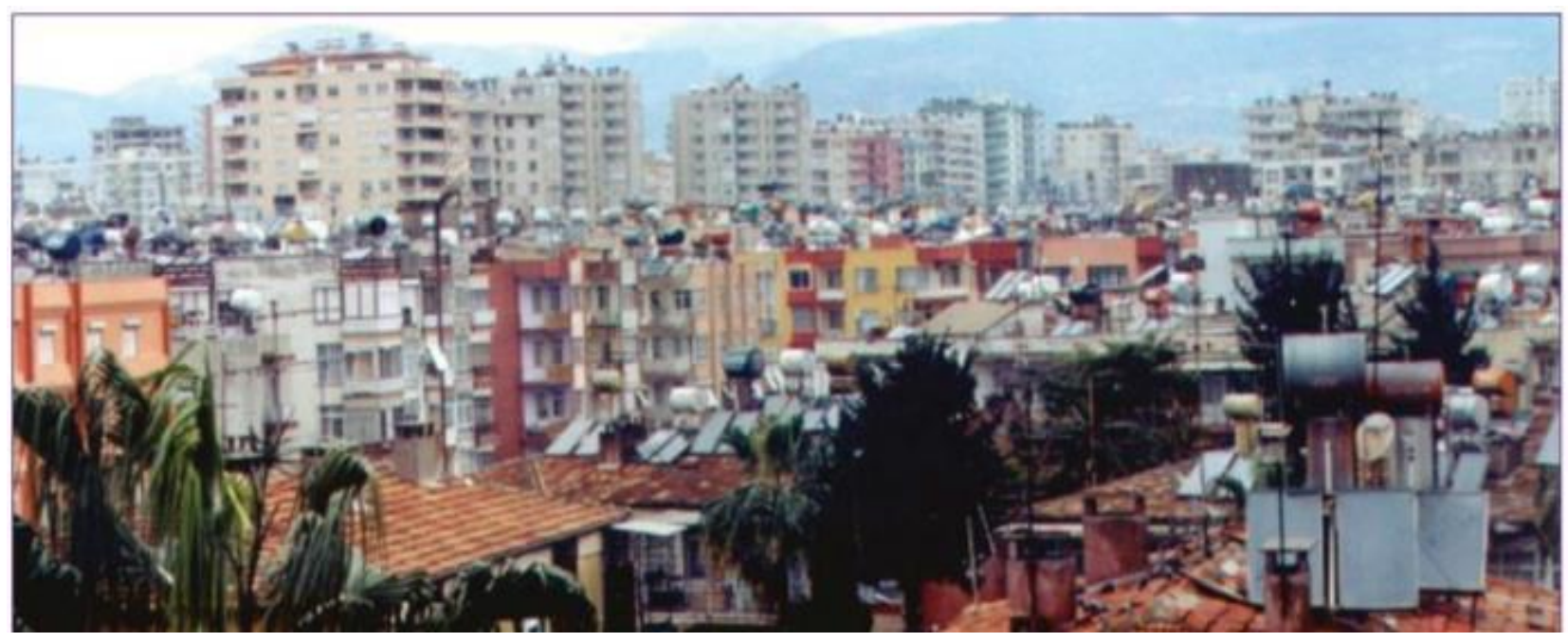

Figure 2. Solar Heating Systems in Mersin Context (Sakınç and Sözen, 2009)

While assembling the components of Solar Heating Systems to the buildings, buildings can be damaged as a result of some unconscious practices. As a result of such applications, it can be said that there are some negative consequences both economically and in terms of the building's existence, and these results affect the entire building. Structural defects, which lead to water leaks, punctures, and breaks, especially on the roofs, arise as a problem that concerns not only the roof but the entire structure (Sakınç and Sözen, 2010).

These impractical and unplanned applications for buildings damage the quality and characteristics of the building. These additions, which have turned into problems in terms of structure, 
also cause extra expenses in financial terms. Every mistake made in terms of structure turns into a situation that needs to be corrected, which forces the user to spend money. Structural problems that start on the roof spread overtime to all parts of the building and consequently damage the entire building.

These interventions to historical buildings that are trying to adapt to the modern period and in need of protection are irreversible mistakes. Damage to the historical heritage, values, and historical fabric increases the questionability of these systems. For this reason, the construction problem, which arises as a result of the presence of solar heating systems in buildings, indirectly affects the sustainability of the cultural heritage.

\section{Material and Method}

\subsection{Material}

The material of study is Solar Water Heating Systems Elements in Sivrihisar Urban Site.

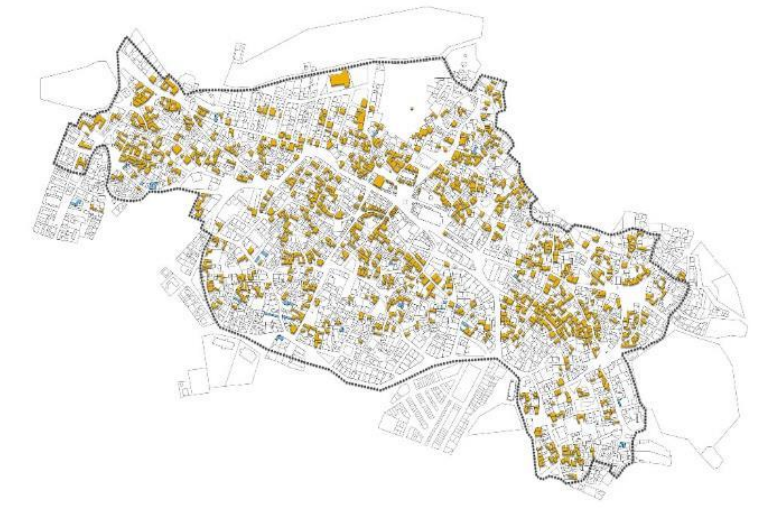

Figure 3: Distribution of Registered Buildings in Sivrihisar Urban Site (Sivrihisar Cultural Inventory, 2019)

Located between Eskişehir and Ankara in Central West Anatolia, Sivrihisar has been able to conserve its historical texture and identity buildings significantly due to the slow development of the district center, although it is close to Ankara, the capital of Turkey and on the ring road route (Doğru, 1997). Also, compared to the other 12 districts in Eskişehir, Sivrihisar is among those with a very high solar energy potential according to the Solar Energy Potential Atlas (GEPA) produced by YEGM, the Ministry of Energy and Natural Resources (Atak, Çabuk, Bakış, and Çabuk, 2019). The interventions in recent years have begun to damage this historical fabric. It can be said that factors such as neglect of the buildings and unqualified additions cause significant aesthetic and structural damage to the buildings.

There are 1076 registered buildings in the urban site area, according to the 2010 Sivrihisar Conservation Development Plan of Eskişehir Province. Two hundred two of these structures have lost their registrations according to the decisions taken in 2015, 2016, and 2017. After these years, there are 874 registered buildings in the region (Sivrihisar Cultural Inventory, 2019). The spread of these buildings in the Sivrihisar Urban Site Area is shown in Figure 3. As of 2017, 701 of the 874 registered buildings have the function of residences within the scope of traditional residential, while 85 are buildings used for industrial and commercial purposes. Apart from these, there are 30 religious buildings (such as cupola, mosque, mausoleum, church), 27 cultural structures (such as a fountain, bathhouse),
16 archaeological sites, seven cemeteries, two military buildings, two administrative buildings, two urban sites. There are also one cemetery and one monument (Sivrihisar Cultural Inventory, 2019). Classification showing the structure type and quality of these structures is given in Table 2.

Table 2. Distribution of Registered Buildings in Sivrihisar Urban Site Area (Sivrihisar Cultural Inventory, 2019).

\begin{tabular}{|c|c|c|}
\hline $\begin{array}{l}\text { Registered } \\
\text { Building }\end{array}$ & Number & Type \\
\hline $\begin{array}{l}\text { Residential } \\
\text { Buildings }\end{array}$ & 701 & Residential(697), Immovables(4) \\
\hline $\begin{array}{l}\text { Commercial } \\
\text { Buildings }\end{array}$ & 85 & Commercial(84), Shop(1) \\
\hline $\begin{array}{l}\text { Religious } \\
\text { Buildings }\end{array}$ & 30 & $\begin{array}{l}\text { Mosque(14), Cupola(4) } \\
\text { Mousoleum(3), Minaret(4), } \\
\text { Masjid(3), Church(1), Namazgah(1) }\end{array}$ \\
\hline $\begin{array}{l}\text { Cultural } \\
\text { Buildings }\end{array}$ & 27 & $\begin{array}{l}\text { Fountain(16), Bathhouse(5), Inn(2), } \\
\text { Külliye(1), Watchtower(1), Bridge(1), } \\
\text { Şadırvan(1) }\end{array}$ \\
\hline $\begin{array}{l}\text { Archaelogical } \\
\text { Sites }\end{array}$ & 16 & $\begin{array}{l}\text { Necropolis(3), Cave Churches(2), } \\
\text { Mounds(6), Archaelogical Field(1), } \\
\text { Ruin(1), Tumulus(2), Arch. } \\
\text { Graveyard(1) }\end{array}$ \\
\hline Graveyards & 7 & Graveyard(7) \\
\hline Urban Sites & 2 & Urban Site(2) \\
\hline $\begin{array}{l}\text { Military } \\
\text { Buildings }\end{array}$ & 2 & Military Building(2) \\
\hline $\begin{array}{l}\text { Administrative } \\
\text { Buildings }\end{array}$ & 2 & Administrative Building(1), School(1) \\
\hline Cementeries & 1 & Cementery $(1)$ \\
\hline Monuments & 1 & Monument(1) \\
\hline Total & 874 & \\
\hline
\end{tabular}




\subsection{Method}

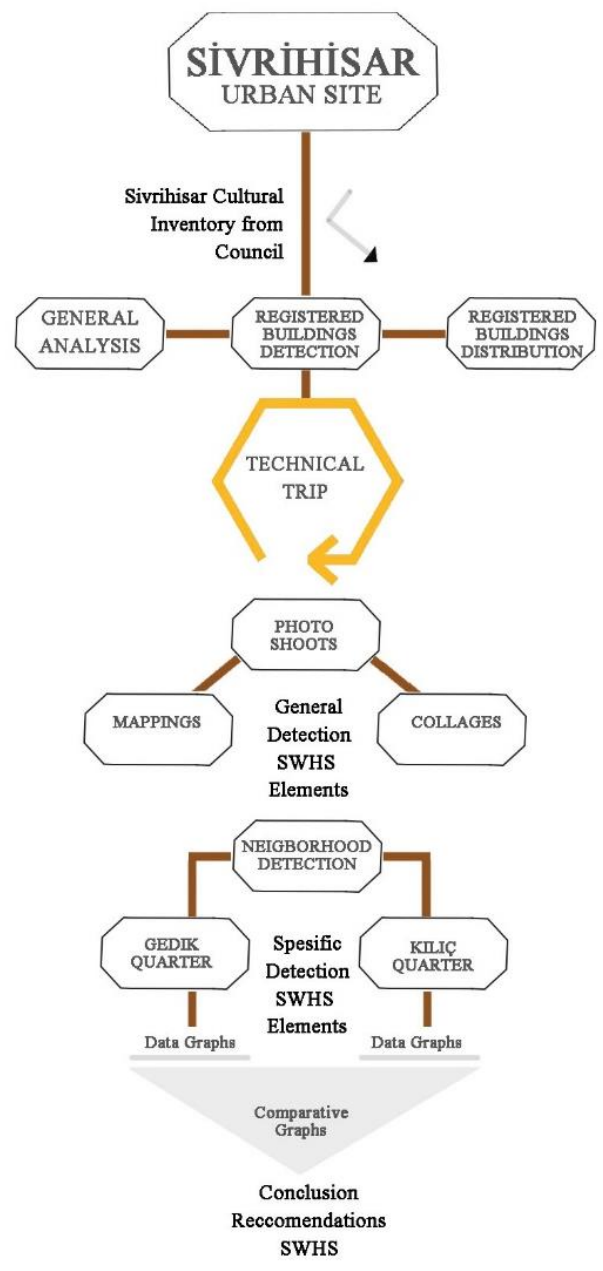

Figure 4: Method Diagram of Study

In this study, various methods were used to analyze the association of solar water heating systems in historical buildings of the Sivrihisar Urban site. First of all, general analyzes of the Sivrihisar urban site were made, Sivrihisar inventory was reached through the Eskişehir Conservation Board, and 874 registered buildings were identified. The buildings reached were divided into categories according to their characteristics. After these procedures, a technical visit was made to the region for the purpose of fieldwork. During this trip, mapping studies and collages were revealed with the photographs taken in the urban site. After the visual data produced as a result of the analysis studies carried out on a general scale, more specific examinations were started.

In the second stage, the neighborhoods in the urban site were determined, and two neighborhoods with the dominant texture on the urban site were selected. For each building on Gedik and Kılıç Neighborhoods, the status of having system elements or not has been examined and conveyed with maps. Then, the analysis data obtained from these two neighborhoods were examined comparatively. Finally, some evaluations were made in line with the data obtained, and suggestions were made (Figure 4).

\section{Results and Discussion}

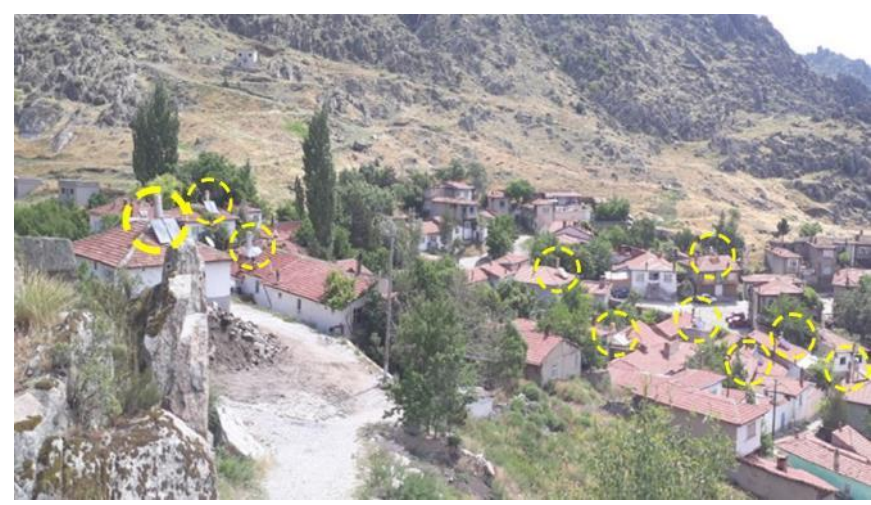

Figure 5: Sivrihisar "Rooftop" Solar Heating Systems

According to analysis made in Sivrihisar, it is seen that almost all of these system additions are located on rooftops (Figure 5). By virtue of the field studies, it has been observed that the problems arising in the light of this information increase in areas where roofs can be observed. Considering that the perception of these system additions in a building directly affects its surroundings, the additions included in the buildings also concern the city's whole.

Although the number of monuments and ruins that have not been damaged due to time and human-made effects is quite low, these structures are preserved and registered due to their "rarity" (Ahunbay, 1996). Owing to the cultural values these structures carry, the interventions should be more careful. The interventions made to the registered buildings in Sivrihisar can also be viewed directly from the clock tower and the surrounding panoramic terrace, which is the highest point where the city can be watched in general and which is the most popular tourist area recently. The watchtower directly encompasses the Sivrihisar Urban Site, and the aesthetic concern of the buildings that are included in the city terrace and can be viewed from this area is even more prominent (Figure 6). Solar Heating Systems components can be detected from this terrace at a distance that human eyes can perceive. Although our eyes are capable of detecting the Andromeda Galaxy at a distance of 2.25 million light-years on a cloudless and clear night, our eyes cannot detect more than 20 kilometers in an average day due to dust vapor, pollution, and dust in the air (Villazon, 2012). Since all buildings with a range of up to 20 kilometers can be perceived from the city terrace with our eyes that can see and perceive to this extent, they can affect the city's texture and identity. (Figure 5).

Apart from that, the system elements included in our perspective from the street scale can be given as an example of the aesthetic problems in residential areas. As seen in Figure 7, these system elements can be included in our perspectives for people who are not on the city terrace while walking on the street. System elements on the registered building, which is included in tourists' perspectives wandering in the historical texture, or the system elements present in non-registered buildings, also cause aesthetic problems. 


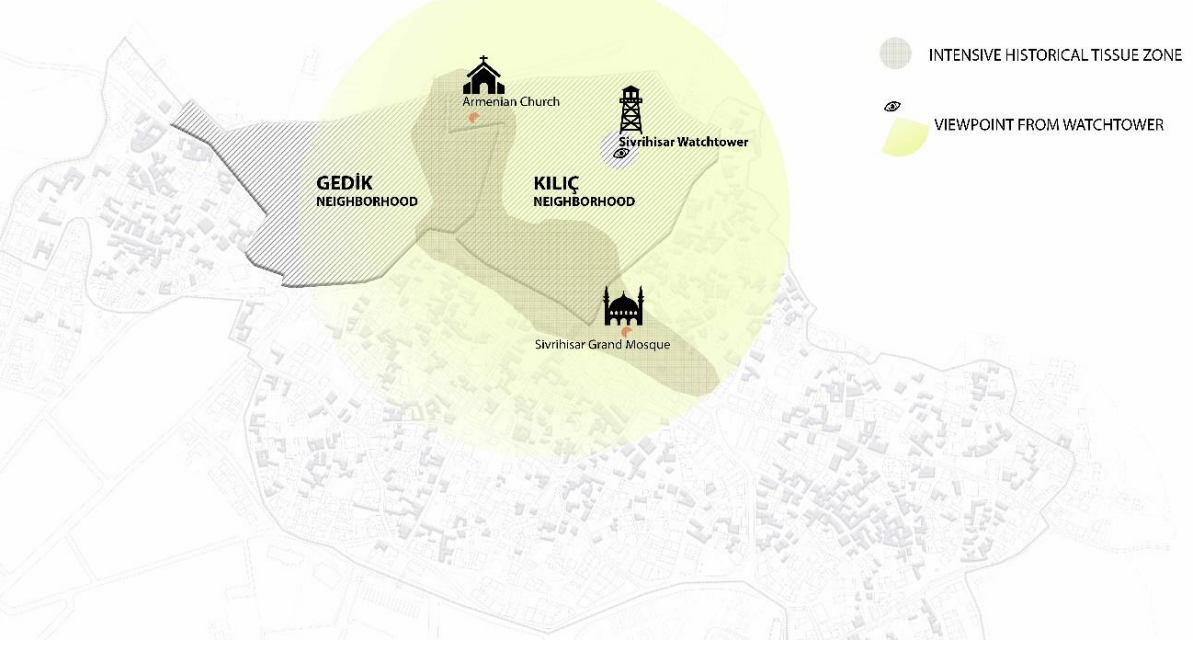

Figure 6. Viewpoint from Sivrihisar Watchtower

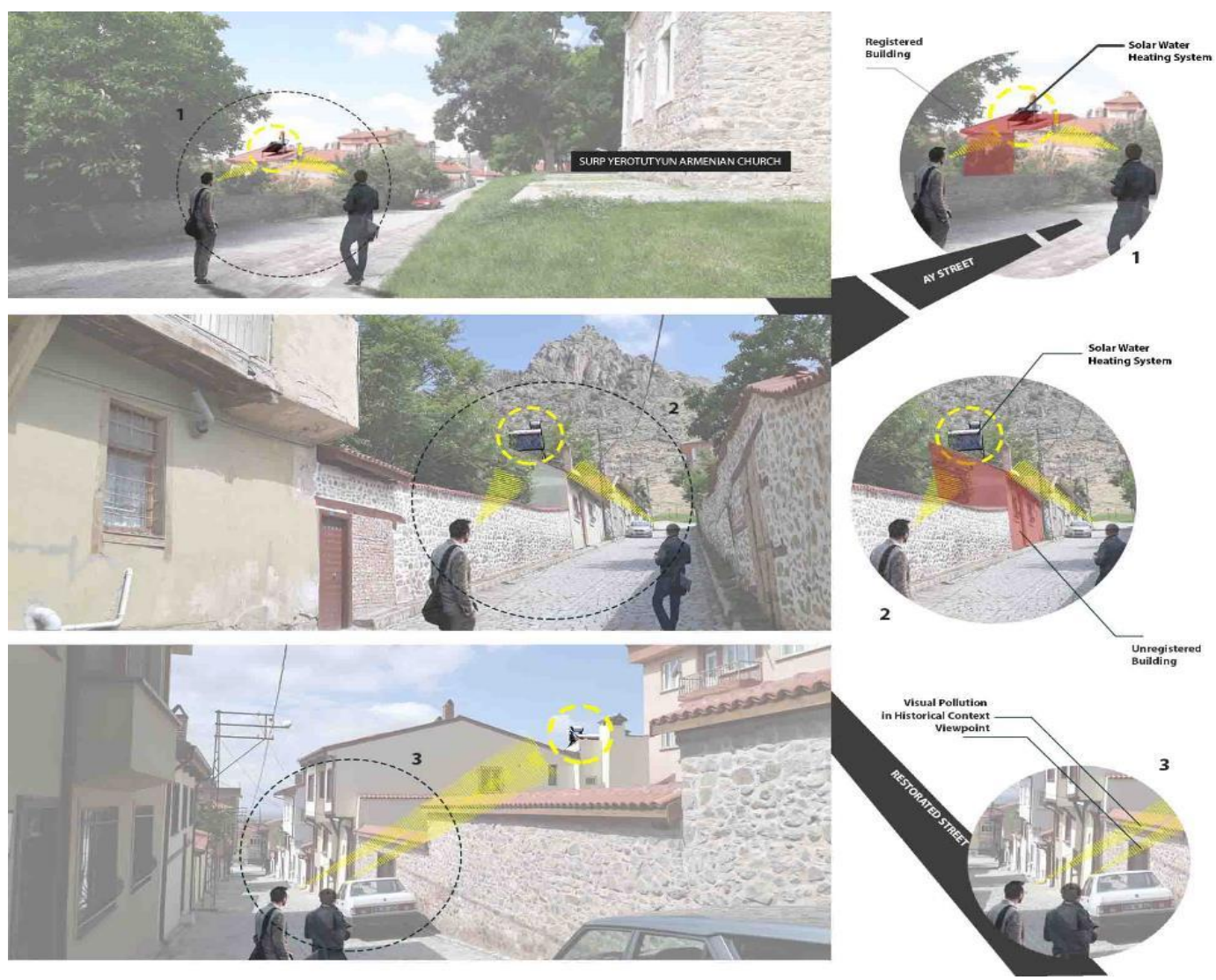

Figure 7. Solar Water Heating Systems in Street View

Sivrihisar's old city texture is scattered over eleven neighborhoods today. It is possible to express this distribution with its main lines: in the north of the city is the Kilıç quarter, which forms the Turkish settlement's core. To the east of it is the Kubbeli, Camii Kebir districts, and the Elmalı neighborhood at the easternmost end of the settlement; the Gedik quarter is located in the west. In the lower part of them, from northwest to southeast, Yenice, Karabaşlı, Karacalar, Cumhuriyet, Demirci, and Kurşunlu neighborhoods are listed (Aksoy, 2014). The distribution of 11 neighborhoods within the urban site is given in Figure 8. When we consider the area in Sivrihisar urban site scale, it is seen that Kılıç and Gedik Neighborhoods have dominant positions in the historic environment. The intense historical texture zone includes cultural landmarks such as Sivrihisar Great Mosque, Surp Yerotutyun Armenian Church, and Watch Tower, and the relations of this stain with Gedik and Kılıç Neighborhoods are given in Figure 8. The watchtower, the most popular tourist attraction of the city, and the panoramic terrace around it directly enclose these neighborhoods. Field studies conducted on the neighborhood scale enabled the buildings in the region to be explicitly examined. Registered and unregistered buildings within the boundaries of the quarter were 
examined one by one, and it was determined whether they have SWHS or not.

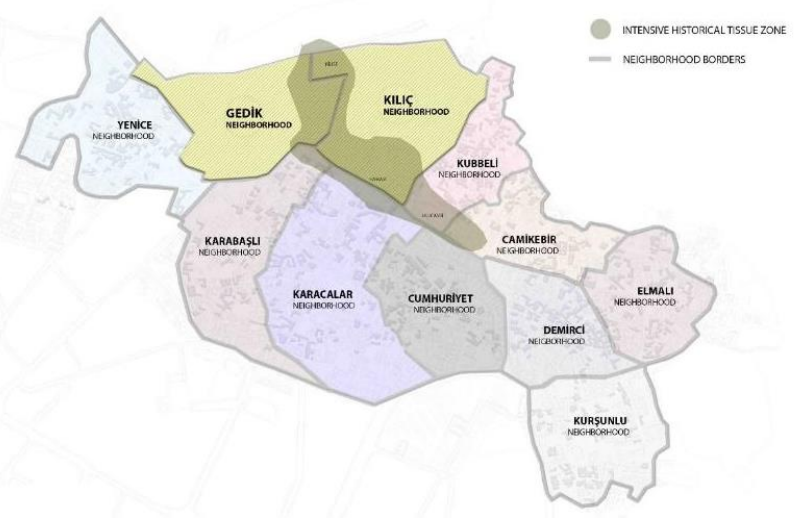

Figure 8. Distribution of the Neighborhoods in Sivrihisar Urban Site

When we consider Kılıç Quarter, which has the watchtower, it can be observed that 15 of 106 registered buildings were used with SWHS. These systems are used in 21 of the 174 buildings without registration (Figure 9). These system additions exist in 36 buildings in total that are within the boundaries of the Kilıç Quarter and can be viewed from the watchtower. Based on the analysis, one building lost its registered feature.
Figure 9. SWHS Distribution Map for Kılıç Neighborhood

When we look at the scale of Gedik Neighborhood, another neighborhood that has a dominant position on the historical texture, while the SWHS was used in 36 of the 191 nonregistered buildings, we encounter 23 SWHS components in 100 registered buildings (Figure 10). We observe that the registrations of two buildings have been dropped. Gedik neighborhood, which is at the border of Kiliç quarter, also has buildings that can be perceived on the watchtower. Most of the 59 buildings that own SWHS are included in the viewpoint over the town.

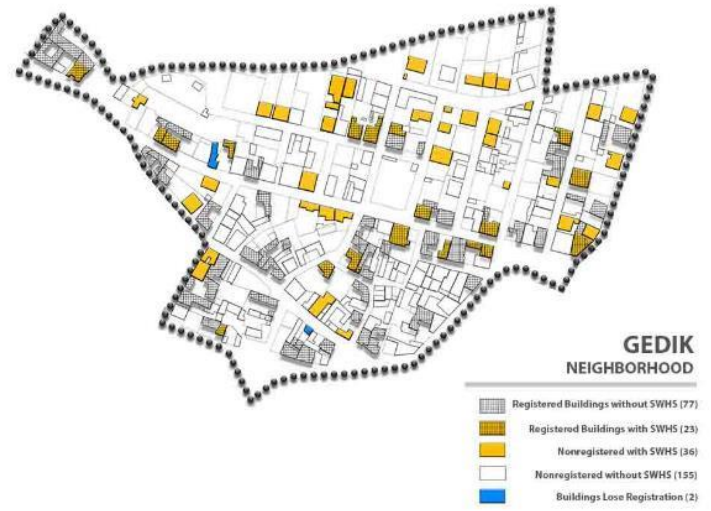

Figure 10. SWHS Distribution Map for Gedik Neighborhood

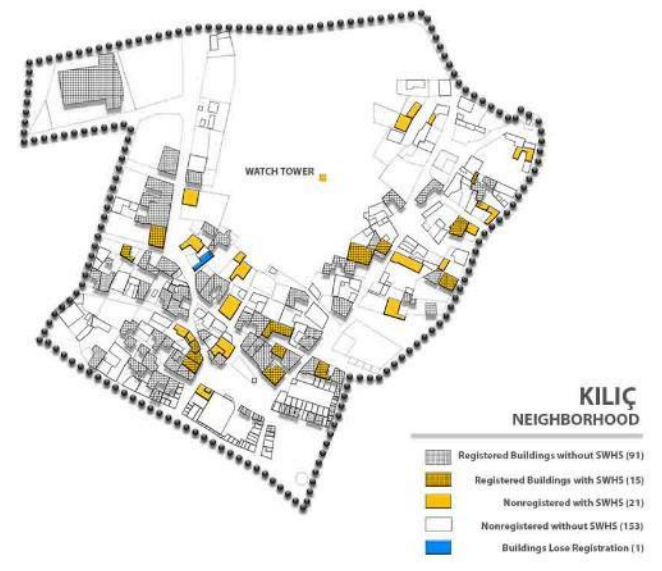

According to the data obtained from the field study analyzes in these neighborhoods, we reach the information that there are 38 registered buildings with SWSH components. These systems exist in 57 unregistered structures. The systems in these buildings can be easily perceived from the City Terrace. The additions have also reached a detectable level when walking on these neighborhoods' streets within the historical site area, apart from

the

city

terrace.

\section{Buildings with SWHS}

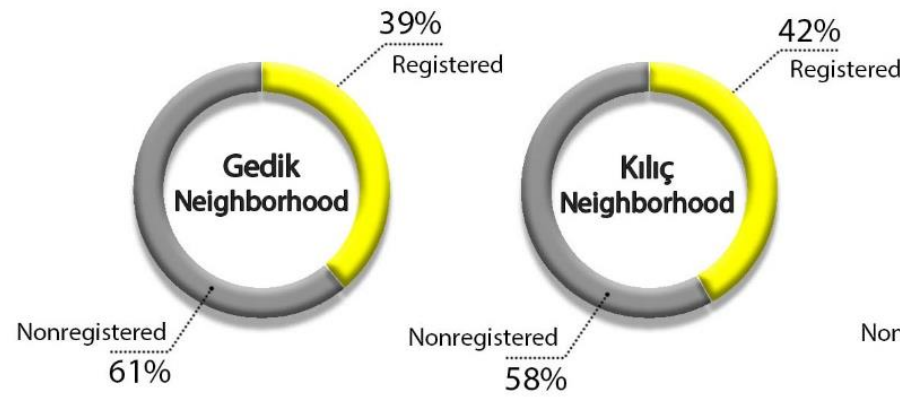

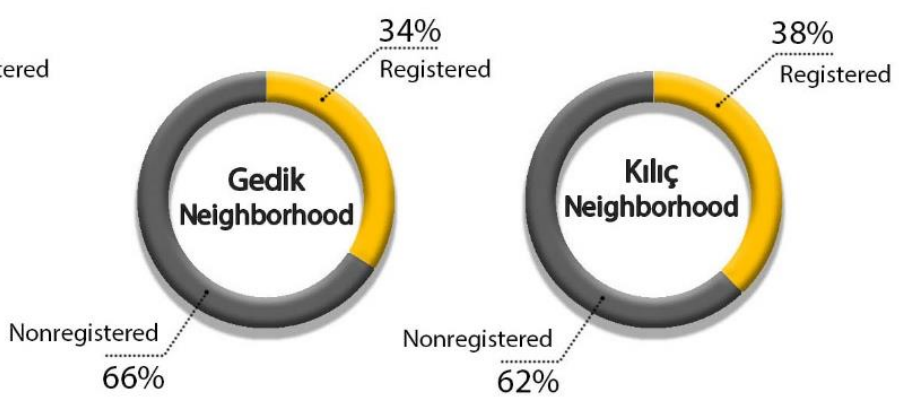


While $34 \%$ of the buildings that do not own an SWHS component in Gedik District are registered, this rate is $38 \%$ in Kılıç District. At the same time, 39\% of the buildings where SWHS exists are registered in Gedik District, while this rate is $42 \%$ in Kilıç District. According to the comparison of these two neighborhoods, the rate of SWHS occurrence in registered buildings of Gedik Quarter is higher than Kılıç Quarter (Chart 1). As shown in a 4-component comparison of these neighborhoods, in a proportioning practice where all buildings exist, $5 \%$ of both registered and buildings with SWHS are found in the Kılıç District. This rate is $8 \%$ in Gedik District. Nonregistered buildings with SWHS in the Gedik neighborhood were determined to be $12 \%$ compared to all buildings. In other words, there are SWHS components in one of every five buildings in the Gedik neighborhood. Unregistered and buildings with SWHS in K1lıç District make up 8\% of all buildings. In this neighborhood, 13 out of every 100 buildings have SWHS components (Chart 2). According to the data obtained from the graph, Gedik district is under the influence of these components more than Kılıç district.

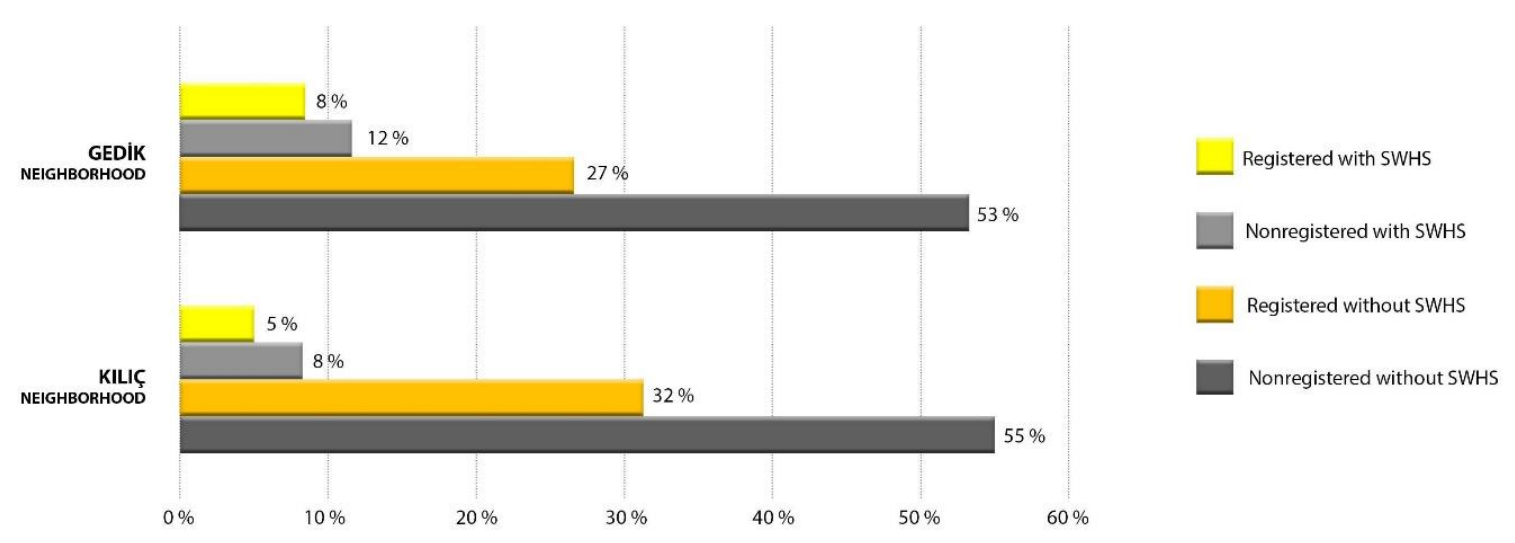

Chart 2. Comparison of Kilic and Gedik Neighborhoods with 4 Components

\section{Conclusions and Recommendations}

Considering that the use of Solar Water Heating Systems, which is required in a sustainable world from an economic and environmental perspective, will become more widespread in the coming years, these systems should be considered essential architectural elements in buildings. These system mechanisms, which have a dominant factor in the buildings' aesthetics and architecture, will be a topic that needs to be considered, and decisions have to be made for the future. For these reasons, for the unity of these systems included in the sustainability principle, with the structures, a holistic design idea that will be considered with all building elements should be taken. It is crucial in terms of aesthetics and construction to regulate the relations of their existence in the historical texture with the buildings.

For this purpose, the urban scale's historical texture was analyzed with the field studies carried out in Sivrihisar urban site, and specific buildings were examined at the neighborhood scale (Gedik and Kılıç). Although the number of these systems in Sivrihisar Urban Site Area, which is the region where the investigations were carried out, has not yet manifested itself on a large scale in the historical site, it is also possible for the future to spread and capture the urban texture. According to the field study analyzes, even if the registered buildings with SWHS components observe in the minority among the entire buildings, the effects and dominance of these minority buildings on the historical urban fabric colud be problem.

In a possible application for these systems on the Sivrihisar Urban Site, it is crucial that the two leading neighborhoods are Gedik and Kılıç Quarters and then spread these practices throughout Sivrihisar. These local-scale applications; it will be possible with the recommendations and sanctions to be made on the building scale beforehand.

On the other hand, it has been observed that these systems are located in the south-facing sloping areas of the roofs in order to benefit from the sun more efficiently. For this reason, the aesthetic suggestions to be made to the buildings should start with the roofs. For the roofs, collectors, and storage tanks, some applications such as gathering together, arranging them, ensuring their harmony with the structure can be made. While applying these principles, some methods should be used; hiding systems, evaluating systems as building elements, using systems as building envelopes (pergola, railing, sun breaker) (Sakınç and Sözen, 2008). Except for the roofs, thanks to the outer courtyards of many buildings in this region, these systems can be moved to these regions easily. In this application, although Solar Energy Efficiency is not as high as in roofs, this efficiency difference may be acceptable in historical buildings. Also, some mechanism changes can be beneficial. It is recommended to prefer systems with forced circulation (pump), which do not force the architecture of the storage tank's position, rather than systems with self-circulating systems. Although these systems cost more, their use should be preferred to solve historical buildings' aesthetic problems.

\section{References}

Ahunbay, Z. (1996). Tarihi Çevre Koruma ve Restorasyon, İstanbul: Yem Publishing.

Aksoy, E. (2014) "Kentsel Gelişmede Ulaşımın Etkinliği: Sivrihisar Örneği”. Eskişehir, Türkiye: T.C. Eskişehir Valiliği Yayın No:22.

Al-Badi, A.H., Al-Badi, M.H. (2012). "Domestic solar water heating system in Oman: Current status and future 
prospects", Renewable and Sustainable Energy Reviews, 18(8): 5727-5731.

Arslan, H. M. (2018). "Determination of the Most Effectıve Solar Energy Water Heatıng System for Hotel Busınesses with Aras and Oreste Methods", Dicle University Journal of Social Sciences. 10(20): 58-69.

Atak, A., Çabuk, S.N, Bakış, R., Çabuk, A. (2019). "Determination of Suitable Sites for Solar Power Plants by Using Weighted Overlay Analysis: Sivrihisar Case", International Journal of Renewable Energy Research, 9(3): 1203-1213.

Doğru, H. (1997). “XV. ve XVI. Yüzylllarda Sivrihisar Nahiyesi, Ankara: Türk Tarih Kurumu Basımevi.

Energy Efficiency Best Practice Programme (2001). "Solar Hot Water Systems in New Housing", General Information Report 88

Eskişehir Council of Cultural Heritage Conservation (2019). Sivrihisar Cultural Inventory, Eskişehir.

Hestnes, A. G. (1999). "Building Integration of Solar Energy Systems", Solar Energy, 67(4-6): p.181-187, 1999.

ICOMOS Turkey (2013). "Architectural Heritage Conservation Declaration".

Kuban, D. (1973). Mimarlk Kavramlarl, İstanbul: Istanbul Technical University Press.

Sakınç, E. and Sözen, M. (2008). "An Approach To Evaluate Solar Active Systems As A Design Criterion”, J. Fac. Eng. Arch. Gazi Univ, 23(1): 21-31.

Sakınç, E. and Sözen, M. (2010). "Solar Hot Water System Matter in Turkey (Mersin Case)", Megaron Journal, 5(1): 110.

Shi, J., Su, W., Zhu, M., Chen, H., Pan, Y., Wang, Y., and Wan, S. (2013) "Solar water heating system integrated design in high-rise apartment in China", Energy and Buildings, 58(3): 19-26.

US Army Corps of Engineers (2002). "Unified Facilities Criteria, Design: Active Solar Preheat Systems".

Villazon, L, How far can we see if unobstructed. 2012 April 27; Available from https://www.howitworksdaily.com/what-isthe-maximum-distance-the-human-eye-can-see-ifunobstructed/ 